\title{
Reading and Writing Workshops: The Student Assistance Psychological Practice in the University
}

\author{
Graziele Aline Zonta ${ }^{1, *}$ (1) \& Andréa Vieira Zanella ${ }^{2}$ (D) \\ ${ }^{1}$ Universidade Federal do Paraná, Curitiba, PR, Brasil \\ ${ }^{2}$ Universidade Federal de Santa Catarina, Florianópolis, SC, Brasil
}

\begin{abstract}
The article analyzes the use of reading and writing workshops as a psychological practice for student support in higher education, by promoting a mediating space for the exercise of creative reading and writing and for problematizing authorship in academic practices. The workshops were held with groups of undergraduate students from two public universities, and the method consisted of dialogue circles and reading and writing activities in different textual genres. Bakhtinian discursive analysis was used to analyze the statements and writings produced by the participants. The results discuss the workshops as a space for psychological assistance capable of promoting the sharing of meanings about academic relations and practices and about the possibilities of being author-reader-writer.
\end{abstract}

KEYWORDS: educational psychology, higher education, literacy, workshops, discourse analysis

\section{Oficinas de Leitura e Escrita: Prática Psicológica de Assistência Estudantil na Universidade}

\begin{abstract}
RESUMO - O artigo analisa o uso de oficinas de leitura e escrita como prática possível para a assistência psicológica estudantil, ao promover espaço mediador para o exercício da leitura e escrita criativa e para a problematização da autoria nas práticas acadêmicas. As oficinas foram realizadas com grupos de estudantes de graduação de duas universidades públicas e seu método consistiu em rodas de conversa e atividades de leitura e escrita em diferentes gêneros textuais. Os depoimentos e textos produzidos pelas participantes foram submetidos a uma análise discursiva de base bakhtiniana. Os resultados destacam as oficinas como espaço de assistência psicológica capaz de promover o compartilhar de sentidos sobre as relações e as práticas acadêmicas e sobre as possibilidades de ser estudante autor-leitor-escritor.
\end{abstract}

PALAVRAS-CHAVE: psicologia educacional, educação superior, letramento, oficinas, análise do discurso

School and Educational Psychology has been constituted, in recent decades, as a field of debates by professionals and researchers that seek to construct knowledge and practices that are responsive to the demands of this broad context of operation. For Oliveira and Marinho-Araujo (2009), School Psychology is, in addition to the professional field of the psychologist, a field of scientific production in which the main objective is to "mediate the processes of human development and learning, contributing to their promotion" (p. 651). The mediation of the psychology professional gains a prominent role in the educational context due to being oriented towards the construction of actions and production of knowledge about and for the subjects in a constant movement of transformation engendered by the learning processes.

Traditionally, professionals in this field have focused primarily on student orientation, as indicated by the research by Bisinoto and Marinho-Araújo (2015). However, the authors recognize that there is currently a movement for the emergence of actions that turn their view critically toward the relationships between the participants in educational contexts, in institutional and transformative perspectives. This condition has required investment in studies that seek to identify the activities prioritized by professionals in the field.

*E-mail: graziele.zonta@ufpr.br

- Submetido: 11/11/2019; Aceito: 01/10/2020. 
Immersed in the educational scenario, School Psychology has been consolidated in the university context in recent decades, an area that has been gaining space in Higher Education Institutions (HEIs). It includes psychology professionals that, supported by their knowledge about other teaching contexts and in other areas of activity, have a tendency to replicate the actions already consolidated in those, with the investment in practices that respond to specific needs of this new field of action imposing a challenge.

Studies highlight the importance of investing, also in the context of HEIs, in actions that involve all the participants of the educational process (Bisinoto \& Marinho-Araújo, 2015; Marinho-Araújo, 2016; Moura \& Facci, 2016). As possibilities aligned with this orientation, we recognize the importance of actions that invest in the students' academic literacy process ${ }^{1}$, considering that reading and writing practices in higher education are produced by the conditions specific to the context of higher education and to the subjects that are involved.

In this line of practice, authors such as Almeida and Pan (2017) propose to overcome the purely pedagogic or therapeutic character common to many interventions, seeking to favor the tensioning of the ways of thinking, feeling and acting in relation to students' reading and writing practices. These actions problematize reading and writing beyond the instrumental acquisition of codes, shedding light on the social, political, psychological, cognitive, linguistic and economic consequences that result from the subjects' immersion in these practices.

In order to break with the individualizing and instrumental view commonly taken of reading and writing practices at the university, we assume the need to promote reflection on specific and relatively stable ways of circulating knowledge, that is, the discursive genres (Bakhtin, 2003), which are constructed among participants of the university world. It is when accessing this world that students start the movement of appropriation of information that belongs to the specific field of science communication and that the conditions for their participation in this discursive sphere are created.

Contrary to what is usually expected of a university student, they do not enter higher education with knowledge of this field or of the academic genres. Most of the texts that circulate through this medium are not written by the students, but for the academic community and do not necessarily belong to the same period in which the readers are, requiring the establishment of dialogue with other authors of their time and with other knowledge (OlaveArias et al., 2013).

For this reason, authors in the field of literacy studies (Alves \& Moura, 2016; Lea \& Street, 2006) defend the importance of addressing academic literacy as a process to be constructed in this context, questioning the fallacy that once literate and having participated in the literacy practices of the previous stages of teaching, students will be able to move smoothly through those of higher education.

Based on these arguments, we can assume that participation in literacy practices linked to the appropriation of academic genres is fundamental for the construction of authorship by students throughout their passage through higher education. From the Bakhtinian perspective of language, authorship involves the axiological positioning of the author-creator in their actions and productions (Bakhtin, 2003). In this process, the author transposes the social valuations of the lived reality to the axiological plane of the work, that is, of their production, giving form to the content experienced from the ethical and evaluative, unique and irreplaceable position that they occupy in the world.

Authorship is, therefore, a concept that involves the comprehension of subjects in relation, situated in a context. Being an author in the academic context presupposes the integration into the discursive field of the production of scientific knowledge and the learning of the means of communication with its participants. The authorship here requires considering the evaluative positions of the participating subjects in relation to the ways in which social practices, such as reading and writing, are produced and produce their practitioners, in order to enable active, responsible positionings that bring to the fore the voice of their authors.

In this debate, it is important to consider the places of voice occupied by the different participants in the university context. These places involve the power relations that are established between students and teachers, intertwined by the conditions placed on the literacy practices in higher education. In this process, institutions tend to determine what is valid knowledge or not and make some practices, content, authors and genres more visible and influential. This results in the orientation of readings recommended to students, as well as in the delimitation of what is said and written by the students. The possibilities of authorship, thus, become responsive to the conditions of the context and the power relations established within it (Barton \& Hamilton, 1998; McLaren, 1988; Zonta \& Zanella, 2020). Therefore, it is necessary to comprehend how reading and writing intertwine in the academic practices that are established between students and teachers, being meanings for them. Considering the School Psychology practice in higher education, it is the responsibility of the professional to problematize the social and institutional context in which the practices are carried out, exercising mediation to create possibilities for the exercise of authorship. In this work, our focus is on how these processes were carried out among university students from two public universities in Southern Brazil.

1 Regarding academic literacy, see Castelló (2014). 


\section{METHOD}

In this intervention study (Dias et al., 2017), we constructed workshops with groups of undergraduate students from two Brazilian federal universities, with the aim of problematizing the possibilities of creation and authorship in reading and writing practices among the students. The mediating activities of the workshops consisted of readings, the written productions of texts and dialogue circles. At each meeting, different genres of texts were used, which are commonly requested of students in the academic universe, such as scientific articles, books and abstracts; as well as texts with which students relate outside this context, such as literary texts, institutional documents, songs and publications on social networks. We sought to provide the participants with a dialogue between academic genres and other genres, as a means to promote the multiplication of meanings about the texts read, the experimentation of different possibilities of aesthetic activity in the written practice and the reflection on the creative process itself.

We based our concept regarding the creative processes on the historical-cultural perspective of Vygotsky (2009), understanding that all creative construction occurs from the (re)composition of aspects of a subject's lived reality in a complex process in which the imagination interweaves memories, thoughts and affections. Accordingly, the proposed work sought to problematize the web that relates reading and textual production to the participants' significant experiences in a process oriented towards new possibilities of (re)creating through written language and for the resignification of themselves as readers-writers.

In order to mobilize the theme of each meeting, the texts worked on were selected by the mediator or were chosen by the participants, according to the orientation of that meeting. Some themes worked on at the meetings were: feelings about entering university; places of voice and silence in the production of knowledge; literary writing; academic writing; institutional documents; production of seminars; and writing on social networks. The reading of the mediating texts was carried out collectively or individually, as decided by the group at each meeting.

After reading, dialogue circles were performed in order to promote the sharing of meanings about the material read and about the genres worked on, and to problematize the possibilities of becoming an author in the different discursive genres that circulate among the reading and writing contexts, particularly in the academic sphere (Branco \& Pan, 2016). The circles also sought to prepare the participants for the written activity that followed them.

The written activities were organized in order to articulate the texts read and the discussions held in the circles. Throughout the workshops, the participants produced texts in different genres, such as short stories, poems, journalistic texts, chronicles, fables, social media posts, article summaries, reviews and songs. The time allocated for the completion of each written activity was defined with the participants. All were invited to read their texts to their colleagues. A new dialogue circle followed the reading of the texts produced, focusing not on the evaluative judgment of the texts, but on the thoughts and affections that involved the writing process ${ }^{2}$.

We based the functioning of the dialogue circles on the concepts of outsideness and dialogism as conceived in the Bakhtinian perspective of language. The concept of outsideness is understood as the surplus of seeing that allows each person to experience the other, to signify them and, reciprocally, to signify themselves. The concept of dialogism is assumed as a condition of alterity, of the recognition of oneself in relationships, insofar as it promotes the clash between the social voices that constitute subjectivity (Bakhtin, 2013). In the context of the workshops, the circles made it possible to promote the circulation of the voices, of the discourses comprehended as socially and singularly constituted, exposing them to possible (re)readings and the construction of new meanings about the university experiences.

Considering the reflections on the role of psychology in higher education, we approached reading and writing from the perspective of group support, not restricting ourselves to thinking about the possible problems in the academic literacy process as individual difficulties of the students. On the contrary, group interventions aim to promote reflections on the context in which reading-writing occurs in institutions and society and on how these practices weave the ethical and social world of life into the world of written creation.

\section{The Groups and the Information Produced}

Reading and writing workshops were held in two public universities: the Federal University of Santa Catarina (UFSC) and the Federal University of Paraná (UFPR). For the formation of the groups in the institutions, a dissemination process was carried out through posters and online publications on the official websites and Facebook pages of the two universities. Two groups were held at UFSC (Group 1 and Group 2), with seven and eight weekly meetings, and one group at UFPR, with six weekly meetings. The meetings with each group lasted approximately two hours. The only criterion for participation was the condition of being an undergraduate student in one of the aforementioned institutions; students from different training centers participated, with ages varying between 18 and 49 years. Each group was attended by eight students, six women

2 The details of the procedures used in the workshops can be found in Zonta (2018). 
and two men. Therefore, the total number of participants in the three groups was 24 students, 18 women and 6 men.

Group 2 at UFSC had the participation of a psychologist from the Office of Student Affairs (PRAE) of that institution. The professional was invited to participate because a contact already existed prior to the beginning of this research between the psychologist of the PRAE/UFSC and the researcher-mediator of the workshops, who is also a psychologist in the student assistance services of a public university. Among the professionals there was an interest in identifying and constructing practices with the student body, so that carrying out this work at UFSC was configured as an opportunity to expand this dialogue and problematize the workshops as possible actions in the field of student assistance.

After the final meeting with Group 2, the participating psychologist was invited to give an interview regarding the work performed. The in-depth interview modality was chosen, characterized by Olabuénaga (1999) as one that seeks to produce the greatest amount of information possible from each question, favoring the comprehension of the meanings, perspectives and interpretations given by the interviewee to their own context. A previously prepared script was used, with questions related to the psychologist's perceptions about the workshops; the meanings about her own participation in the work; the relationship between the participants; and possible contributions of the workshops for student assistance and psychology. The interview lasted approximately two hours and was audio recorded. Therefore, the research corpus was constituted by: texts produced by the participants during the meetings; testimonies provided during the dialogue circles, which were audio recorded and subsequently transcribed; written evaluations of the workshops carried out by the participants during the final meeting of each group; and the transcript of the interview with the PRAE/UFSC psychologist.

The information produced was submitted to a discursive analysis from the Bakhtinian perspective (Jobim and Souza $\&$ Carvalho, 2016). This procedure that sought to identify the multiple social voices that were present in the statements of the participants and the researcher, as recorded in the material produced. From the analysis of these voices, the problematization of the discursive contexts in which the university allows its participants to speak and be heard was performed.

Regarding the written evaluation carried out by the participants, although we recognize this as a pertinent way of evaluating group work, its limitations need to be highlighted. We consider that the statements and the writing at the moment when the participants were asked to make an evaluation of the work, more intensely valued positionings oriented directly toward the researcher and her work. We believe that the statements and writings produced at other moments of the meetings, not directly responsive to the request for evaluation of the work, are more favorable to other meanings, presumed to respond to the expectations the participants' had when they signed up for the workshops and the difficulties experienced in the academic context. Considering this, throughout the article, when the evaluations refer to those carried out in writing, they will be identified in parentheses after their reproduction, together with the identification of their author ${ }^{3}$.

\section{RESULTS AND DISCUSSION}

\section{The Group as a Space of Contact between Voices-consciences}

An initial aspect highlighted by the participants about the workshops was their significance as a space that provided them with voices and listening. With the sharing of different perspectives, the workshops favored, according to their statements, the collective identification of feelings/ thoughts that were previously signified as exclusive by the participants, putting them in circulation:

For me, the workshop was a place where I could share experiences from the university with different people who had a view of all that, I was able to exercise various things that I would not do of my own free will. (Larisse, Tourism, UFPR - written evaluation).

Most of the members of this group are from different courses. Although we are in the same university, we come from very diverse realities. Being with these people made me feel more open to dialogue and to identify other perspectives. (Nathan, Chemistry, UFPR - written evaluation).

The group came together very well, making things flow and giving body to thoughts that until then I thought were just mine. (Mellina, Letras, UFSC - written evaluation).

From the transcribed statements, we recognize that the workshops created space for the meeting of students from different courses in an environment that favored the acceptance of their differences. This experience favored the expansion of their views to the student universe, strengthening them in a relational context, beyond the academic sphere.

3 A consent form was signed by all workshop participants that agreed to participate in the study. When signing the form, the participants chose whether to be referred to by their names, initials or pseudonyms created by them in the study reports. Their options were respected in this study. 
The statement of the PRAE/UFSC psychologist, in turn, corroborates the evaluation of the participants, indicating aspects relevant to the intervention in the group format, based on her experience in student assistance:

So I think it was cool because... "Wow! The guy who is there at the other Center also went through an experience similar to the one I'm going through". And the group is great at that, right? There are things that could happen due to the dynamics of the group and, if it were individual, they would never happen. And it is the world of the graduation. So it's an opportunity to, in a protected space, respectfully, talk about it too, within a certain measure that they knew how to respect (Elisa, psychologist - UFSC).

The transcribed statements highlight the possible character of the group to promote not only the sharing and mutual recognition of thoughts and affects among the participants, but also the articulation between the voices that circulate in the group and in the broader context of the institution. Elisa highlighted how, in the group, the voices of students from different Centers, or Sectors, met and were revoiced, giving rise to new meanings for the "world of the undergraduate course", in addition to those that the participants already knew.

From these statements, we conceived the possibility of bringing to light the "arena of struggles" (Bakhtin, 2013), which allows the visibility of the dissonance of voices between the participants, to be a condition for the effect of the group in the transformation/expression/reflection of the participants. In this arena, the shared meanings encounter and lose other meanings, constructing new meanings - a movement made possible by the "dialogical nature of human thought, the dialogical nature of the idea". (p.98).

In addition to the emphasis given to the possibility of recognizing the voices that circulate among students, the participants valued the group as a space where they felt heard and welcomed, differentiating this place from that established in the classroom. The importance of this free exposure space for the students is highlighted when we observe how the fear of judgment by colleagues and teachers was among the apprehensions presented by the students that were reluctant to expose their opinions or clarify doubts in the classroom. In order to exemplify this point, we present a dialogue that took place in one of the circles, between the workshop mediator and the participants Ana Maria and STR, both students of Literature at UFSC who were at different stages of the course:

Ana Maria: There is a lot of passivity from the students, a great lack of interest in the undergraduate course. In the elevator, I already overheard professors, saying: I'm not going to teach undergraduate classes anymore, they don't read the texts, they just want to mess about". But it's not only what they said, I see that the students do not participate. The professors sometimes bring up a political issue, you know? (...) And the students do not participate, they wait until the coffee break to comment on what they were going to say to the professor.

Mediator: But I think it has to do with our history as students as well. We go to learn and the professor goes to teach. You are afraid to speak out...

STR: And there is something else. These quiet ones don't want to be exposed either: "oh, I'm going to ask a stupid question and the others are going to laugh... I'm going to say something wrong... "I see it like this, my colleagues who enter quietly and stay silent until the end, get marks of 8.0 and 9.0 all through the year. The one that is exposed, who asks the question, gets marks of 6.0 and 7.0. So there's a whole... "I'm protecting myself here, I'm not talking... I enter quietly..."

In STR's statement, we recognize that the silence of the classmates is meant as fear of exposing opinions contrary to those of the professor, as they would be subject to reprisals through receiving low grades. There is also the identification of the fear of being ridiculed by colleagues when making comments and questions that would be considered inappropriate.

For Ana Maria, the silence was recognized as lack of interest of her classmates and here her voice is added to the voice of teachers that identified in the students the passive posture highlighted by her. These meanings do not include the reasons why many students do not take a participatory position during classes, which certainly involves a much more complex plot, interwoven by the feelings, thoughts, wishes, goals of each student in relation to their courses. However, we can assume that both the reading produced by Ana Maria and the reading of STR are directed toward the voice of different classmates and some professors, involving the students in a contradictory dynamic: on the one hand they are invited/impelled by their professors and colleagues to actively participate during the classes; on the other hand, they feel intimidated by them, giving up the opportunity to get involved in the network of relationships that supports the collective construction of knowledge.

As a consequence, this movement will have repercussions on the students' actions in their academic practices, as it is from this network that the recognition of the subjects in their practices and their possibilities of creation are established. Authorship, which in this perspective derives from the positioning of subjects in relations with peers and also in works produced in the academic context, is put into tension. If the students are afraid to speak up, they do not take an active position in their statements, actions and works produced.

Furthermore, if we comprehend that academic practices, as put in place today, often respond to market interests (Mancebo, 2010), favoring highly competitive relationships in an oppressive character and disfavoring the active positioning of students in their relationships and actions, then we can locate in the welcome and sharing of the group, 
factors that propitiate new modes of relationship. The group then became a context different from that of the competition of the classroom, in which the participants were able to express their thoughts and affects in another way, with freedom and without fear. This condition tends to favor the resignification of themselves in the relationship with the others and their possibilities of creation and expression.

It was also possible to evaluate that the support of the group, with the discussions generated becoming an instrument for the articulation between the activities proposed in the workshops and the academic activities. The dialogue between the workshop mediator and Lorena, a student of Literature at UFSC, illustrates this point. This conversation took place during the dialogue circle of the final meeting, when the group sought to make a joint evaluation of the workshops:

Mediator: I remember, when we had that tense day, that Lorena shared her experience of more difficult situations (...) I thought about you a lot during that week...

Lorena: I thought about you a lot too. You said it like this: "You are more critical than you imagine". Then I left thinking: guys, I'm critical (laughs). To what point? Then I started to measure, it was what you said that instigated me to measure.

The situation mentioned in the conversation refers to a dialogue circle that occurred in a previous meeting in which Lorena shared her anxieties about being obligated in her course to take a critical position, in both the academic work, and during classes and internships. Interwoven with her concerns were the difficulties in determining what it means to be critical in the university and how much one can assume critical postures in the relationship with their course professors, who are marked by strong social and institutional hierarchies. Despite actively participating in the dialogue circles, proposing several questions that moved the debates among the participants and critically questioning the practices assumed in her course, Lorena did not seem to recognize a critical posture in her positionings. Through this dialogue, we evaluated how the discussion in the group led the student to reflect on herself, on the demands placed by the university in the process of her academic and professional training and on her responsiveness to these demands.

\section{The Group Mediation of the Creative Process}

In addition to the effects on the formation of bonds and on new possibilities for active-responsive positioning of the students in the academic space, the dynamics that interwove the mediating activities provided the resignification of the conditions of the participants as authors-readers-writers of different texts.

The student STR, 45 years old, who participated in Group 2 of UFSC, came from public education and was studying Literature-Portuguese. From the beginning of the workshops, she stated that the appropriation of grammatical aspects in the writing process was one of the biggest obstacles she faced in the production of academic works. Throughout the workshops, when she was invited to read the texts she produced, she reported feeling anxious, not because she was embarrassed to speak in public, but because of her concern with presenting an impeccable text in relation to the so-called standard form.

In the dialogue circles, STR's evaluations of her own texts were marked by an intense control over possible grammatical errors, a situation that seemed to lead her to direct her creative choices toward the textual genres with which she already had skills, such as reviews and short stories, which were the most requested in their course:

Talking is not the problem. It is to write and then... this issue of punctuation (...) how many paragraphs, how many lines there are in each paragraph, commas, repeating words, verb agreement. Understand? I speak very well. Now, this part here is what terrifies me (STR, Literature, UFSC).

As the meetings took place, STR received positive feedback from her group colleagues regarding her writing, a situation that contributed to encourage her towards a more free and untroubled production of the norms. Consequently, the reading of the texts for her colleagues was carried out in a less apprehensive way during the meetings and STR showed herself to be more available and calm in relation to her production.

In the fifth meeting, it was possible to provoke STR to take a chance on writing something that she did not feel so authorized to do. On that day, the participants had been invited to bring to the meeting a non-academic text that had marked their lives and to read it to their colleagues, commenting on the meanings and affects that motivated the choice. The reading of excerpts from novels, short stories, poems and music chosen by the participants was accompanied by a brief discussion about the formal characteristics of these genres and their possibilities of expression/communication in different contexts. Then, the written activity consisted of jointly defining a theme to guide the production of a text, with each participant needing to write it in a different genre from those presented at the meeting, or in any other that they knew or wanted to create. This activity was intended to engender reflection on different possibilities for objectifying the meanings regarding a common theme, in different genres, and to provide space for the exercise of challenging writing, not normally carried out by the participants. In this way, we sought to tension the limits of the participants' recognition as writers, raising them to new possibilities. The jointly defined theme was "work".

STR, for this meeting, had selected a short story by Machado de Assis to read to her colleagues, as she explained, at that point in her course, the work of this author was being 
studied, and she had already read several of his stories in response to academic demands. Thus, when choosing a genre for writing as proposed in the workshop, STR volunteered to produce a short story, initiating the following dialogue that took place between the participant and the mediator:

STR: I'm going to write a short story.

Mediator: But don't you write a lot of short stories?

STR: It's that... What we write the most is the review and short story... It's what we practice there, right? [in the Literature course].

Mediator: (To the group) Think about it like this: what do you want to challenge yourself in? Who writes a lot of short stories, writes poetry...

STR: Ah! A poem... A piece of poetry... I never wrote poetry...

Mediator: Then write poetry, STR.

While STR was writing her poem, the following dialogue took place:

STR: Could it be just four lines?

Mediator: It can be any way you want it. It may even be a new style of poetry, if you want to try...

STR continues writing:

STR: But I think it rhymes... It needs to rhyme, right?

Mediator: It doesn't need to rhyme, no. It could be haiku, it could just be a stanza...

STR: Look, I created a little verse. I never created poetry, I never wrote anything! First time. My God!

STR reads the poem she created:

Noble craft

I wake up early for work;

I drink coffee in a frenzy;

Repeated gestures, difficult routine.

Another day of duty done.

Mediator: Look at that! Your first poetry here in the reading and writing workshop!

STR: Oh how funny! What don't we do? (laughs) Was it cool?

We can assess that STR responded to the challenges presented to her in the workshops with a process of overcoming the conditions that restricted her written creation to academic demands and that, in turn, maintained good grades in the evaluations.

In the dialogue, the mediator caused STR to assume an active and affective posture, a necessary condition for the creative process. We assume that this movement did not occur only at the moment of the production of the transcribed dialogue, nor only with STR; it occurred with all the participants, students and mediator, entwined by the activities and the context of the group in process; a welcoming/challenging group.

As highlighted by Maheirie et al. (2015), we emphasize the importance of considering creation in its social construction process, which is not to be confused with notions of innate talent or vocation. Based on Vygotsky's perspective, Maheirie et al. (2015) analyzed how complex psychological processes are articulated in any creative production, modifying the creative subject itself: "That is, from the creation, the subject modifies their affectivecognitive possibilities, which, in turn, transforms life and the reading of their context" (p. 58).

Thus, in the creative process of her poem, STR was prompted to reflect on the writing skills she had already used and those she had not yet tried, pushing herself to write a text she had never written, a poem. Affects were interwoven with thoughts in this process, while the participant sought to follow the rules that she assumed existed for this genre: "Could it be just four lines? It needs to rhyme, right?

In the end, the poem produced was appropriated as a concrete result of her creative process, and the affects of admiration and surprise that accompanied this moment indicate the recognition of her new possibilities as a writer. Thus, we can evaluate how STR freed herself from affective and social bonds that conditioned her writing to restricted types of texts, which affirms Maheirie et al. (2015): "The objectification of the creation process can provide the subject with an overcoming of their situation, a movement of overcoming in their history, a transformation in their feelings and emotions towards a more emancipatory posture" (p. 60).

It is important to note that STR, being an older student than her classmates and coming from a public school, claimed that her writing was behind that of her younger colleagues and those coming from private education, exemplifying this difference with the grammatical and structural problems that she recognized in her texts. For her, good writing seemed to be understood as something restricted to those that had a good basis for textual production from previous years of teaching.

Accordingly, we can say that the employment of the group work method, constructed through the use of dialogue circles and activities mediated by different textual genres, proved to be important for this student's authorial recognition, promoting conditions for the expression of new creative possibilities that could also tension the meanings 
constructed about being behind. We can also conceive that, if we had only used academic texts, or other types already studied in the Literature course, and without the presence of the group as a sounding board for STR's creative conditions, it would have been more difficult for the student to overcome the anxiety and the intense control she exercised over her productions, avoiding launching herself into new challenges.

It is also pertinent to discuss some developments regarding the signification of this anxiety that STR manifested in relation to the writing of the texts. This feeling seemed to contain traits from the school and academic demands, constituting itself more as a response to the contextual conditions in which her writing was being carried out than as a condition intrinsic to her, as commonly found in clinicalpsychological contexts. A broad view of the relationship between the social context and the aspects of subjectivity, which are often reduced to a supposed individual nature, is essential for the performance of professionals working in Higher Education student assistance, particularly for the psychology professional.

\section{Reflections on the Social Construction of the Authorship}

The possible transformations of/in writing practices were also reflected in the process experienced by Larissa, a student of the Psychology course at UFSC. For her, the activities carried out in the workshops strengthened her search for more creative writing compared to the more formalized and rigid productions in the academic field. The same activity mentioned in the previous item was also carried out in Group 1, in which Larissa participated, with the participants being invited to write, from different genres of texts, on a jointly defined theme. In this group, the theme defined for the production was "paradigm".

Larissa chose to challenge herself by writing a fable, a production she said she had never made. In the narrative created, the rabbit, Julieta, who lived in the Enchanted Forest, was discouraged by her animal friends from crossing the river that isolated her community and discovering what was on the other side. Determined, Juliet decides: "Do you want to know something? I won't stop doing something that I believe because others think I shouldn't do it. I will not allow that. " The rabbit then builds a raft to cross the river and, on the other bank, finds the "Paradise of Flowers", a place inhabited by friendly animals that also believed that on the other side of the river there were "strange and dangerous beings, and because of that, they had never crossed". The story ends with the residents of the two communities building a bridge to connect the two banks and with the presentation of the moral of the story, characteristic of the

4 Excerpts from the text written by Larissa are presented in quotes. fable genre: "Only those that allow themselves to take risks will remove the blindfold".

The risks of exposure, the fear of taking innovative actions, the meaning of the unexplored and unknown as dangerous, the naturalization of difference as something to be avoided were some aspects that emerged from Larissa's fable and that can be articulated to the students' voice in the academic context as a resonance of the social relations in a broader context. In the creation of her text, Larissa tensions these questions, bringing to the group aspects of our social existence that need to be questioned so that new possibilities of action and relationship can be created. The bridge created by Larissa as a metaphor in her text affirms the need to seek to know the unknown and to recognize oneself in it, strengthening the social group in which one participates. It also shows the movement of encounters between voices, as occurred in the workshops, and the conditions for reconstructing themselves in the relationships established there.

In this movement, the conditions to create and recreate themselves through written language appeared to Larissa, articulating the elements of her social and academic experiences in an imaginative process that took place in the story she presented in her fable. In the narrative, Larissa expressed her ethical-aesthetic assessment of the relationships of her social environment and positioned herself as the author-creator through characters that took on certain ethical-evaluative positions and through a plot that alluded to the actions of people in that environment. With the help of imagination, Larissa transcended her lived experiences, signifying them in terms of possible new experiences, a process that is present in any creative movement, as advocated by Maheirie, et al. (2015).

In her assessment of her production process, Larissa signified the space of the workshops as a catalyst for this exercise of creating the text and her own creative-authorial conditions:

How do we think we are not capable, right? This is something that... when I started I thought: "My God, I'm not going to be able to do it, I never wrote a fable! I'm going to make a fable! No, but maybe I will... "And imagine! This short time we stayed here, how much we can use our time to do these things... And believe more in ourselves (Larissa, Psychology, UFSC).

Glimpsing new ways of looking/creating/communicating and producing conditions to do this should be part of the academic routine, guiding the discussions that involve the question of authorship. We agree with Girardello (2012) when he affirms that the training of the researcher is also constituted as the training of the author, of someone capable of saying something new in a new way: "authorship does not only reside in the original equation of concepts or in the crossing of unpublished data, but also in the possibility of communicating this material" (p. 299). 
Linking authorship to the possibilities of performing communication, we return to Bakhtin (2003) when stating that every statement is positioned in a dialogical chain and, therefore, responds and addresses the participants in that chain. Comprehending the positioning conditions in the university's dialogical field and, consequently, the modes of communication through different types of texts, among them academic texts, is essential for the construction of authorship.

For the participants, the mediating activities of the workshops seem to have favored this comprehension, a situation that can be illustrated through some statements:

At first, I thought the workshop would be to learn to write correctly, working on grammar, among other things. However, it showed much more, because before writing and expressing yourself well, you need to understand what you want from that text, what it has of you and what it wants to convey, that is, its essence (Alba, Law, UFPR - written evaluation).

This experience emphasized in me the need to reflect on the "how", "for what", "for whom" and "why" of writing, which is true when one has authorship (Larissa, Psychology, UFSC - written evaluation).

It is worth mentioning that, as Alba noted in her evaluation, many participants sought the workshops believing that it was technical, grammatical training, along the lines of some writing workshops offered at educational institutions. When the broader aims of the proposal were clarified, among them, to discuss the relationship of students with reading and writing at the university, they engaged in work and ended up appropriating a new way of thinking about texts, as Larissa said, articulating them to their contexts of production and reading, to their enunciative chains.

These objectives and the work approach were also signified by the psychologist Elisa, who highlighted her success in assisting the students in the process of appropriating the ways of creating texts and of the academic world:

As a group, they realized that it was not a workshop in which they were going to learn how to write a course completion work or write an article. No, but we are going to look at what these things are and to what extent I can appropriate them for this to be a more known world. And in which I also like to read, in which I also like to write, in which I can think, I can build my bridges over time to be more familiar with this academic world, without giving up what is a reference for me (Elisa, psychologist PRAE - UFSC).

We understand that this work is relevant to theoretical perspectives in the psychological field of practice in higher education that propose, based on a historical-cultural orientation, the construction of relational practices, as proposed by Marinho-Araújo (2016) and Oliveira and Marinho -Arambia (2009). In this orientation, it is understood that it is not possible to assume the existence of purely individual phenomena, requiring action based on the relationships between subjects, on the meanings about the processes they experience and on the historical and social contexts in which they are inserted.

Finally, it is worth mentioning the evaluation of this work in terms of its contribution to the construction of the knowledge and practices in the students. Lucas, 18, a Physics student at UFSC, made the following assessment:

For me, the coolest thing I found about the workshop was that your project had a path aimed at students and that you chose a theme that would cause some change within society. Because I see many doctoral and master's projects that are purely academic projects, without seeking any social change. I think that it is very important when someone does this. I also liked that you didn't want this to be just for you, you wanted to make room for other people to continue this project, even if it wasn't with your name and everything. I think this is really cool, I think that was what I liked the most about this project, you have given this opening to continue (Lucas, Physics, UFSC).

In this historical moment in which productivist logic largely guides the production of knowledge and practices in the academic field, Lucas' statement reveals a voice that questions the production of many works that do not necessarily offer a real contribution to the area in which they operate, but that are added to the number of publications produced by their authors. This condition establishes a tension between researchers and students who reflect and refract academic practices, often directing the question of authorship towards the desire to have social recognition by their peers, a process that denies the character and the social and historical commitment of the production of knowledge.

Lucas' statement echoes our concern to develop a study that could provoke some positive movement in the participants and in the student community, creating conditions so that it could also be appropriated by other professionals that work with assistance in higher education and that aspire, as we do, to expand the debate on academic literacy and relationships in the university context.

Also regarding the possibilities of expanding this practice, we can assess that the work presented potential for the formation, among the students themselves, of multipliers of spaces similar to those of the workshop, in the university context. During the meetings with Group 2, the participants decided to create a Facebook page designed to publish literary texts, initially written by UFSC students, and later by the external community. The page was entitled Abraços Literários (Literary Embraces), a name jointly defined by the participants of the group. Also in 2016, these participants developed, along with a professor from their course, an extension project linked to 
the Facebook page, in which they promoted meetings for reading, discussing and creating texts, along the lines of the workshops presented here.

We believe that these initiatives reveal the students' motivation to continue constructing spaces for the exercise of creative reading and writing. They also reveal the desire to maintain the bonds created in the groups and to expand the network of students and writers motivated to construct places of voice and listening, of sharing, of strengthening and of mutual support.

\section{FINAL CONSIDERATIONS}

After the completion of the workshops, we can conclude that the work carried out, a psychological intervention in student assistance with groups of university students, allowed the production and recognition of meanings that circulated among the students and that would have possibly remained invisible if the work had focused on individual attention. The circulation of these meanings in a collective space of expression and discussion enabled mutual support among colleagues, and the revoicing of thoughts and affects in the other's voice, allowing the creation of new ways of being and acting. The challenges posed, the support provided, the constant encouragement, and the welcoming of differences and difficulties were the strategies used in the aesthetic workshops that configure this psychological practice in student assistance as a unique practice.

We also assessed that this intervention practice format is relevant for strengthening listening among students and psychology professionals in the educational context. At this point, the professional can assist in a comprehension of the relational construction of the meanings expressed by the participants in the dialogue circles, exploring student support paths based on their professional experience, their knowledge of the subjective constitution and their reading about the group process that is constructed throughout the workshops. Furthermore, the psychologist, as a university professional, offered institutional listening, which may favor the search for actions with the units of the institution involved in the production of the difficulties presented by the participants, mediating their discussion.

We believe that the workshops, as a psychological practice to support students, fulfill an ethical-aestheticpolitical function in the university context. The tensioning of the meanings produced by the participants regarding their conditions of creation and authorship, and the provocations to launch themselves towards what is presented to them as a challenge, help to discover possibilities of being and acting that previously did not find means of existence. In turn, when these group activities are carried out, their effects are multiplied, because when a participant (re)creates their conditions of being an author-reader-writer, these conditions also extend to the other students of the group, as this acts as a catalyst for the transformation movement of each and every one.

This movement that connects and produces subjects among subjects also raises the debate on issues that extend beyond the context of the group, such as the social places attributed to and assumed by different participants in the academic context and the responsibility of the university, not only in the training of students that will be future professionals, but also in the paths of guidance for the constitution of author and creator subjects. These are the challenges that the study presents for future investigations and psychological practices in Higher Education Institutions.

\section{REFERENCES}

Almeida, A. B., \& Pan, M. A. G. S. (2017). Contribuições bakhtinianas para o estudo das práticas de leitura e escrita na universidade: Autoria, gêneros científicos e identidade profissional. In M. A. G. S. Pan, L. Albanese, \& N. L. Ferrarini (Orgs.), Psicologia e educação superior: Formação e(m) prática (pp. 75-98). Juruá.

Alves, M. F., \& Moura, L. O. B. M. (2016). A escrita de artigo acadêmico na universidade: Autoria x plágio. Ilha do Desterro, 69(3), 77-93. https://doi.org/10.5007/2175-8026.2016v69n3p77

Bakhtin, M. (2003). Estética da criação verbal (4 ${ }^{\mathrm{a}}$ ed.). Martins Fontes.

Bakhtin, M. M. (2013). Problemas da poética de Dostoiévski (5 ed.). Forense Universitária.

Barton, D., \& Hamilton, M. (1998). Local Literacies: Reading and writing in one community. Routledge.

Bisinoto, C., \& Marinho-Araújo, C. M. (2015). Psicologia escolar na educação superior: Panorama da atuação no Brasil. Arquivos Brasileiros de Psicologia, 67(2), 33-46. http://pepsic.bvsalud.org/scielo.php?script=sci_arttext\&pid $=$ S1809-52672015000200004

Branco, P. I., \& Pan, M. A. G. S. (2016). Rodas de conversa: Uma intervenção da psicologia educacional no curso de medicina. Revista Psicologia: Teoria e Prática, 18(3), 156-167. http:// dx.doi.org/10.5935/1980-6906/psicologia.v18n3p156-167

Castelló, M. (2014). Los retos actuales de la alfabetización académica: Estado de la cuestión y últimas investigaciones. Enunciación, 19(2), 346-365. https://doi.org/10.14483/10.14483/udistrital. jour.enunc.2014.2.a13

Dias, L. R. R., Zanella, A. V., \& Tittoni, J. (2017). Oficinas de fotografia na pesquisa-intervenção: Construção de coletivos de trabalho. Revista Nupem, 9(16), 158-174. https://doi. org/10.33871/nupem.v9i16.144

Girardello, G. (2012). A escrita antes do texto: De cozinhas, teares e ateliês. In L. Bianchetti \& P. Meksenas (Orgs.). A trama do conhecimento: Teoria, método e escrita em ciência e pesquisa ( $2^{\mathrm{a}}$ ed., pp. 287-300). Papirus. 
Jobim e Souza, S., \& Carvalho, C. de S. (2016). Ética e pesquisa: O compromisso com o discurso do outro. Revista Polis e Psique. 6(1), 98-112. https://doi.org/10.22456/2238-152X.61385

Lea, M. R., \& Street, B. V. (2006). The "academic literacies" model: Theory and applications. Theory into practice, 45(4), 368-377. https://doi.org/10.1207/s15430421tip4504_11

McLaren, P. L. (1988). Culture or canon? Critical pedagogy and the politics of literacy. Harvard Educational Review, 58(2), 213 235. https://doi.org/10.17763/haer.58.2.n106615465585220

Maheirie, K., Smolka, A. L. B., Strappazzon, A. L., Carvalho, C. S., \& Massaro, F. K. (2015). Imaginação e processos de criação na perspectiva histórico-cultural: Análise de uma experiência. Estudos de Psicologia (Campinas). 32(1), 49-61. http://dx.doi. org/10.1590/0103-166X2015000100005

Mancebo, D. (2010). Trabalho docente na educação superior brasileira: Mercantilização das relações e heteronomia acadêmica. Revista Portuguesa de Educação. 23(2), 73-91. https://doi.org/10.21814/rpe.13987

Marinho-Araújo, C. M. (2016). Inovações em Psicologia Escolar: $\mathrm{O}$ contexto da educação superior. Estudos de Psicologia (Campinas). 33(2), 199-211. https://doi.org/10.1590/198202752016000200003

Moura, F. R., \& Facci, M. G. D. (2016). A atuação do psicólogo escolar no ensino superior: Configurações, desafios e proposições sobre o fracasso escolar. Psicologia Escolar e
Educacional. 20(3), 503-514. https://doi.org/10.1590/21753539201502031036

Olabuénaga, J. I. R. (1999). Metodologia de la investigación cualitativa. Universidad de Deusto.

Olave-Arias, G., Rojas-García, I., \& Cisneros-Estupiñán, M. (2013). Deserción universitaria y alfabetización académica. Educación y Educadores, 16(3), 455-471. http://www.scielo.org.co/scielo. php?script=sci_arttext\&pid=S0123-12942013000300004\&ln $\mathrm{g}=$ en\&tlng=es

Oliveira, C. B. E., \& Marinho-Araújo, C. M. (2009). Psicologia escolar: Cenários atuais. Estudos e Pesquisas em Psicologia, 9(3), 648-663. http://pepsic.bvsalud.org/scielo.php?script=sci arttext\&pid=S1808-42812009000300007

Vigotski, L. S. (2009). Imaginação e criação na infância: Ensaio psicológico: Livro para professores. Ática.

Zonta, G. A. (2018). Letramento acadêmico e a construção da autoria em oficinas estéticas: Prática em psicologia junto à assistência estudantil na universidade [Tese de doutorado, Universidade Federal de Santa Catarina]. Repositório Institucional da UFSC. https://repositorio.ufsc. br/handle/123456789/214245

Zonta, G. A., \& Zanella, A. V. (2020). Estudantes negros/as na universidade pública: Tensões na e desafios para a educação superior. Revista Práxis Educacional, 16(41), 591-613. https:// doi.org/10.22481/praxisedu.v16i41.6642 